58). He then went to Birmingham as a lecturer in chemistry, becoming senior lecturer in inorganic chemistry in 1964. Dr. Peacock is distinguished for his researches in the field of inorganic compounds of fluorine and has more than fifty publications to his credit. He has spent several periods working in the United States at the Argonne Laboratories. He is a prominent leader in the Scout and Rover Movement and is an enthusiastic vice-president of the University of Birmingham Athletic Cross Country Club.

\section{Commonwealth Education Liaison Committee}

IN a written answer in the House of Commons on April 29, the Parliamentary Secretary to the Ministry of Overseas Development, Mr. A. E. Oram, stated that Mr. A. R. Thomas represented the United Kingdom on the Commonwealth Education Liaison Committee. The terms of reference of the Committee were to consider matters of principle arising from schemes of Commonwealth cooperation in education which might be referred to it, and any suggestions for further improving Commonwealth co-operation in education to ascertain what information would be of value to member Governments and to suggest the most convenient manner of obtaining it, and to act generally as a centre of reference to develop and improve Commonwealth co-operation in education; to undertake such functions as are by agreement assigned to it from time to time consequent on Commonwealth Education Conferences-these would include publishing reports on the Commonwealth Scholarship and Fellowship Plan, improving arrangements for Commonwealth co-operation, preparing material for further Commonwealth Education Conferences, and advising on requests for assisting in concluding bilateral arrangements; to undertake, subject to the normal method of implementing co-operation through bilateral contracts, such other functions as seem necessary and feasible to develop and improve Commonwealth co-operation in education.

\section{High-energy Physics}

IN reply to a question in the House of Lords on April 13, the Minister of State for Education and Science, Lord Bowden, said that the Government would pay its contributions to the normal expanding programme of the European Organization for Nuclear Research, and the size of these contributions for 1965 and 1966 had already been agreed. The administration had formally proposed that storage rings should be added to their present machine and the Government was now considering whether the merits of the proposal justified the expenditure involved. The design study of the possible $300-\mathrm{GeV}$ accelerator was not yet complete and to assist this study the Government had put forward for appraisal a possible site for such a machine near Mundford in Norfolk; however, this did not imply any commitment to participate in the building of a European $300-\mathrm{GeV}$ accelerator. It was hoped to reach a decision about the storage rings in June and this would add £5-6 million a year to the expenditure from 1967-68, to which Britain should contribute about onequarter. The big machine, if it were decided to build it, would cost at least $£ 120$ million, but he thought that this figure would be very considerably exceeded. The decision whether to proceed would not be taken until the autumn and would depend entirely on the total resources available for nuclear physics in Britain and in Europe. The programme for the European Organization for Nuclear Research was decided by a committee including representatives of all the participating countries.

\section{Nuclear Propulsion of Merchant Ships}

RePLyiNG for the Government in a debate in the House of Commons on the nuclear propulsion of merchant ships on April 15, Mr. R. Mason, the Minister of State, Board of Trade, pointed out that, while a working reactor could be designed and built, and a hull and engine produced of suitable configuration for operating with it, building a prototype ship was not an end in itself. The question was whether the construction and testing of a prototype would provide sufficient information to lead to a design for a genuinely economic merchant ship. There were two other more difficult questions: When would nuclear power prove economic for merchant ships? At what stage would it be best for a country with limited resources to throw in such resources as it could devote to this particular field of technology? The Padmore Group estimated that a development programme would cost some £15 million over about five years and envisaged a continuing programme of research and development beyond that period. So far, industry had shown little enthusiasm for bearing even a proportion of the costs in excess of those of building and operating a conventional ship equivalent to the proposed nuclear ship. There was need to examine carefully not only the channels of expenditure on a prototype leading to the successful development of a design for an economic merchant vessel, but also the benefits which could be expected to accrue from such excesses. These benefits would depend on the extent to which the design evolved was superior to those developed elsewhere. The Government had no alternative but to examine the whole matter afresh and it was not yet ready to indicate what its decision would be.

\section{Teaching Mathematics in Schools}

IN reply to a question in the House of Commons on May 6, the Secretary of State for Education and Science, Mr. A. Crosland, said that the Schools Council was conducting a general review of the sixth-form curriculum. This review included a study of sixth-form mathematics, and the Council was publishing a bulletin on primary mathematics as well as collaborating with the Nuffield Foundation in a primary mathematics project. Secondary mathematics, including sixth-form mathematics, was being studied by the 'School Mathematics Project', directed by Prof. Thwaites of the University of Southampton, and the Department of Education and Science was organizing some short courses for mathematics teachers. A committee, with Sir Neill Mott as chairman, which recently examined the supply of graduate school teachers of mathematics, recommended in its report a continuing expansion of university mathematies departments and a broadening of the range of courses which they offer, in order to provide the schools with a sufficient supply of teachers of mathomatics.

\section{The Patents (Employees' Inventions) Bill}

The Patents (Employees' Inventions) Bill, which received a second reading in the House of Lords on April 27, has the simple purpose of restoring the law governing rights in employees' inventions to what it was believed to be before the case of Patchett versus Sterling Engineering Co., Ltd., was decided in the House of Lords in 1955. In moving the second reading, the Parliamentary Secretary to the Board of Trade, Lord Rhodes, explained that before 1949, when Section 56 (2) of the Patents Act was enacted, where was no statutory or other provision. under which an employee-inventor in private industry had the chance of obtaining some reward for the exercise of his inventive skill. A Departmental Committee had been set up in 1944 under Sir Kenneth Swan as chairman to consider what changes were desirable in the Patents and Designs Act. This committee had recommended that the High Court and the Comptroller of Patents should be empowered to apportion the benefit of an invention or a patent between the employer and the employee who made the invention, in circumstances where it could be said that neither party was exclusivoly entitled to the whole benefit of the invention or patent. This recommendation led to Section 56 (2) of the Patents Act, 1944, but when the case 